\title{
Chemical Profile, Cytotoxic Activity and Oxidative Stress Reduction of Different Syringa vulgaris L. Extracts
}

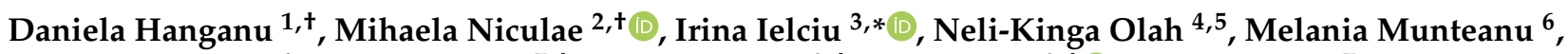 \\ Ramona Burtescu ${ }^{4}$, Răzvan Ștefan ${ }^{7,+}$, Loredana Olar ${ }^{2,+}$, Emoke Pall ${ }^{2,+}{ }^{+}$, Sanda Andrei ${ }^{7}$, Dan C. Vodnar ${ }^{8}\left({ }^{\circ}\right.$, \\ Daniela Benedec ${ }^{1,+(\mathbb{B}}$ and Ilioara Oniga ${ }^{1}$ (D)
}

1 Department of Pharmacognosy, "Iuliu Haţieganu" University of Medicine and Pharmacy, 400010 Cluj-Napoca, Romania; dhanganu@umfcluj.ro (D.H.); dbenedec@umfcluj.ro (D.B.); ioniga@umfcluj.ro (I.O.)

2 Department of Clinical Sciences, University of Agricultural Sciences and Veterinary Medicine, 400374 Cluj-Napoca, Romania; mihaela.niculae@usamvcluj.ro (M.N.); loredana.olar@usamvcluj.ro (L.O.); emoke.pall@usamvcluj.ro (E.P.)

3 Department of Pharmaceutical Botany, "Iuliu Haţieganu” University of Medicine and Pharmacy, 400010 Cluj-Napoca, Romania

4 PlantExtrakt Ltd., Rădaia, 407059 Cluj-Napoca, Romania; neli.olah@plantextrakt.ro (N.-K.O.); ramona.burtescu@plantextrakt.ro (R.B.)

5 Department of Medicinal Chemistry and Pharmaceutical Industry, Faculty of Pharmacy, "Vasile Goldiş" Western University of Arad, 310414 Arad, Romania

Citation: Hanganu, D.; Niculae, M.; Ielciu, I.; Olah, N.-K.; Munteanu, M.; Burtescu, R.; Ștefan, R.; Olar, L.; Pall, E.; Andrei, S.; et al. Chemical Profile, Cytotoxic Activity and Oxidative Stress Reduction of Different Syringa vulgaris L. Extracts. Molecules 2021, 26 3104. https://doi.org/10.3390/ molecules26113104

Academic Editors: Nazim Sekeroglu, Anake Kijjoa, Sevgi Gezici and Luciana Mosca

Received: 31 March 2021

Accepted: 19 May 2021

Published: 22 May 2021

Publisher's Note: MDPI stays neutral with regard to jurisdictional claims in published maps and institutional affiliations.

Copyright: (c) 2021 by the authors. Licensee MDPI, Basel, Switzerland. This article is an open access article distributed under the terms and conditions of the Creative Commons Attribution (CC BY) license (https:/ / creativecommons.org/licenses/by/ $4.0 /)$.
6 Department of Environmental Chemistry, Faculty of Pharmacy, "Vasile Goldiş” Western University of Arad, 310414 Arad, Romania; munteanu.melania@uvvg.ro

7 Department of Preclinic Sciences, Faculty of Veterinary Medicine, University of Agricultural Sciences and Veterinary Medicine, 400372 Cluj-Napoca, Romania; rstefan@usamvcluj.ro (R.Ș.); sandrei@usamvcluj.ro (S.A.)

8 Department of Food Science and Technology, University of Agricultural Sciences and Veterinary Medicine, 3-5 Mănăștur Street, 400372 Cluj-Napoca, Romania; dan.vodnar@usamvcluj.ro

* Correspondence: irina.ielciu@umfcluj.ro

+ These authors contributed equally to this work.

Abstract: Syringa vulgaris L. (common lilac) is one of the most popular ornamental species, but also a promising not comprehensively studied source of bioactive compounds with important therapeutic potential. Our study was designed to characterize the chemical composition and to assess the antioxidant and cytotoxic properties of ethanolic extracts obtained from $S$. vulgaris $\mathrm{L}$. flowers, leaves, bark, and fruit. The chemical profile of the ethanolic extracts was investigated using chromatographic (HPLC-DAD-ESI ${ }^{+}$, GC-MS) and spectral (UV-Vis, FT-IR) methods, while the protective effect against free radicals was evaluated in vitro by different chemical assays (DPPH, FRAP, CUPRAC). The cytotoxic activity was tested on two tumoral cell lines, HeLa, B16F10, using the MTT assay. Significant amounts of free or glycosylated chemical components belonging to various therapeutically important structural classes, such as phenyl-propanoids (syringin, acteoside, echinacoside), flavonoids (quercetin, kaempferol derivatives) and secoiridoids (secologanoside, oleuropein, 10-hydroxy oleuropein, demethyloleuropein, syringalactone A, nuzhenide, lingstroside) were obtained for the flowers, leaves and bark extracts, respectively. Furthermore, MTT tests pointed out a significant cytotoxic potential expressed in a non-dose-dependent manner toward the tumoral lines. The performed methods underlined that $S$. vulgaris extracts, in particular belonging to flowers and leaves, represent valuable sources of compounds with antioxidant and antitumoral potential.

Keywords: Syringa vulgaris L. flowers; bark; leaves; fruit; Oleaceae polyphenols; secoiridoids; antioxidant; cytotoxic

\section{Introduction}

The Oleaceae is an important family among flowering plants, comprising 25 genera, with over 600 species that are spread worldwide in a wide variety of habitats, especially in 
the temperate and subtropical climates [1,2]. The most well-known genera belonging to this family are Olea, Forsythia, Fraxinus, Syringa, Jasminum, and Ligustrum, including species that have economic importance, food and oil plants, perfumed plants, or ornamental species [2]. Among these genera, in the European flora few species can be found, especially belonging to the genera Fraxinus (e.g., Fraxinus excelsior L.), Ligustrum (e.g., Ligustrum vulgare L.), Syringa (e.g., Syringa vulgaris L.) and Forsythia [1]. The Syringa genus is one of the most widely known among these genera, being spread in the Western and Eastern part of Eurasia and comprising two species, Syringa vulgaris L. and Syringa josikaea J. Jacq. ex Rchb. The two species are differently spread along the European continent: $S$. vulgaris can be found on the Balkan Peninsula and in the southern part of the Carpathians, S. josikaea in the northern parts of the Carpathians and both species can be found in the western parts of the continent [3]. The genus comprises more than 40 species distributed around Europe and Asia. Most of these species are deciduous shrubs and trees [4].

The species $S$. vulgaris, the common lilac, is the most widely spread of these two species, being cultivated as an ornamental species all across the European continent [1] and for the perfumes industry [5]. In addition, the species has known various uses, especially in traditional medicine. The more frequently used medicinal product is represented by the inflorescences. In Greece, an infusion of the inflorescences is used internally to treat gastro-intestinal troubles (bloating) and externally as a massage for the treatment of gout and rheumatism [6]. Same external use is cited in the Serbian traditional medicine for this medicinal product in combination with fruit of Aesculus hippocastanum, for the treatment of varicose veins and rheumatism [7]. Flowers of the species are also recommended as antipyretics and appetizers as a decoction in Bulgaria, while Italian traditional medicine describes the use of bark, fruit, and leaves also as a decoction for their astringent and antipyretic effect [8]. Leaves of the species are recommended in Hungarian ethnopharmacology for the treatment of bleeding wounds, joint and muscle aches [9]. Similar species belonging to the same genus (e.g., S. oblata Lindl., S. pinnatifolia Hemsl., S. reticulata (Blume) H. Hara var. amurensis (Rupr.) J. S. Pringle, S. pubescens Turcz. and S. pubescens subsp. patula (Palib) M. C. Chang \& X. L. Chen.) proved to have similar traditional uses. Thus, Chinese sources cite the traditional use of all these vegetal medicinal products (flowers, leaves, barks), but also of roots, branches and fruit, especially for the treatment of gastro-intestinal disorders, joint inflammations, infections, or asthma [5].

Scientific data on the species support the uses that are cited in traditional medicine, being connected to the antioxidant [10,11], antimicrobial [12], anti-inflammatory [13,14] and antipyretic properties [4,5] and inhibitory effects on blood stasis [15]. Studies were performed on similar species belonging to the genus Syringa, as S. pinnatifolia [12,16], but the vast majority were performed on the $S$. vulgaris species $[1,10,11,13-15]$. The compounds that are responsible for these activities are sesquiterpenes [12], hydroxycinnamoyl derivatives and secoiridoids or secoiridoid glycosides [1,13], phenolic compounds [10,11,14,15], lignans [14,16], phenylpropanoids and iridoids [14]. Regarding vegetal medicinal products that were tested, they were represented by flowers $[10,13,15]$, barks $[11,14,16]$, stems [12], fruit [10], leaves [11] or all these [1]. Nevertheless, information on this species, on its medicinal uses and on the compounds that are responsible for these uses remain scarce [1].

Taking all of this into consideration, the species of the genus Syringa appear to be important sources of compounds, proving at the same time important medicinal uses. These species need further investigation, in order to bring further evidence for their introduction in therapy and for the investigation of their bioactive ingredients and mechanisms of action underlying the pharmacological effects they exhibit, as these data remain scarce [1,4]. Therefore, the novelty and originality of this study is represented exactly on its main purpose, which is represented by evaluating the chemical composition and testing the antioxidant and cytotoxic activities of extracts belonging to different parts of the species: flowers, leaves, bark, and fruit. Moreover, the study aims to perform a comparison between these extracts, regarding their composition and biological activities, with the final purpose of highlighting the potential of flowers, which may represent an important medicinal 
product that has anti-proliferative potential and may be used in the therapy of different forms of cancer.

\section{Results and Discussion}

\subsection{HPLC-DAD-ESI ${ }^{+}$Analysis}

Results obtained for the HPLC-DAD-ESI ${ }^{+}$analysis of phenolic compounds can be found in Table 1.

Table 1. Quantification and identification of phenolic compounds ( $\mu \mathrm{g} / \mathrm{g}$ dry vegetal product) in different $S$. vulgaris extracts by HPLC-DAD-ESI ${ }^{+}$analysis.

\begin{tabular}{|c|c|c|c|c|c|c|c|c|}
\hline $\begin{array}{l}\text { Peak } \\
\text { No. }\end{array}$ & Compound & $\underset{(\mathrm{min})}{\mathbf{R}_{\mathbf{t}}}$ & $\begin{array}{l}\mathrm{UV} \lambda_{\max } \\
(\mathrm{nm})\end{array}$ & $\begin{array}{c}{[\mathbf{M}+\mathbf{H}]^{+}} \\
\quad(m / z)\end{array}$ & $\begin{array}{c}\text { Syringa vulgaris } \\
\text { Leaves }\end{array}$ & $\begin{array}{c}\text { Syringa } \\
\text { vulgaris Bark }\end{array}$ & $\begin{array}{l}\text { Syringa vulgaris } \\
\text { Flowers }\end{array}$ & $\begin{array}{c}\text { Syringa } \\
\text { vulgaris Fruit }\end{array}$ \\
\hline 1 & $\begin{array}{l}\text { p-Coumaroyl-glycolic } \\
\text { acid }\end{array}$ & 3.16 & 332 & 223 & $3814.80 \pm 0.96$ & $788.46 \pm 0.58$ & $6748.16 \pm 2.03$ & $1094.85 \pm 1.05$ \\
\hline 2 & Secologanoside & 9.71 & 233 & 391 & $17,539.42 \pm 0.5$ & $3020.98 \pm 1.65$ & $27,663.00 \pm 0.6$ & $467.04 \pm 0.36$ \\
\hline 3 & Syringin & 12.27 & 265 & 373 & $9245.97 \pm 0.54$ & $74,535.30 \pm 2.3$ & $14,653.98 \pm 0.5$ & $1214.39 \pm 0.89$ \\
\hline 4 & 10-Hydroxy-oleuropein & 13.19 & 235 & 556 & $2153.98 \pm 0.89$ & $8943.89 \pm 1.44$ & $3405.45 \pm 0.88$ & $300.31 \pm 1.25$ \\
\hline 5 & Acteoside & 13.95 & 324 & 625 & $5813.26 \pm 1.02$ & $2658.10 \pm 0.88$ & $9408.78 \pm 0.59$ & - \\
\hline 6 & Echinacoside & 15.13 & 328 & 787 & $4537.26 \pm 0.45$ & $38,299.52 \pm 0.1$ & $7417.81 \pm 1.23$ & $2151.03 \pm 0.71$ \\
\hline 7 & $\begin{array}{l}\text { Quercetin-rutinoside } \\
\text { (Rutin) }\end{array}$ & 15.78 & 256,355 & 611 & $4779.29 \pm 0.35$ & $1604.54 \pm 1.23$ & $7642.07 \pm 0.56$ & $72.32 \pm 0.99$ \\
\hline 8 & Ligstroside & 16.10 & 275 & 525 & $6921.53 \pm 1.25$ & $24,820.71 \pm 2.0$ & $11,019.22 \pm 0.21$ & $565.12 \pm 3.01$ \\
\hline 9 & Demethyl oleuropein & 16.41 & 231 & 527 & $28,607.49 \pm 0.71$ & $6396.82 \pm 0.55$ & $35,729.89 \pm 0.2$ & $5345.42 \pm 0.21$ \\
\hline 10 & Oleuropein & 17.12 & 280 & 540 & $4224.40 \pm 0.89$ & $9139.07 \pm 0.78$ & $6744.01 \pm 0.58$ & - \\
\hline 11 & Kaempferol-glucoside & 17.42 & 265,341 & 449 & $2377.10 \pm 0.21$ & $1690.59 \pm 0.25$ & $3814.93 \pm 1.02$ & $462.39 \pm 0.66$ \\
\hline 12 & Syringalactone A & 17.96 & 223 & 511 & $8457.43 \pm 0.65$ & $17,161.82 \pm 1.3$ & $13,652.60 \pm 0.6$ & $1380.14 \pm 1.22$ \\
\hline 13 & Nuzhenide & 18.33 & 275 & 687 & $9928.59 \pm 1.02$ & $129.65 \pm 1.03$ & $15,893.68 \pm 0.3$ & $1365.43 \pm 0.5$ \\
\hline 14 & Oleuropein-aglycone & 18.85 & 280 & 379 & $7541.38 \pm 1.56$ & $42,796.39 \pm 2.0$ & $12,078.46 \pm 0.7$ & $1195.76 \pm 0.25$ \\
\hline
\end{tabular}

Note: Values represent the mean \pm standard deviations of three measurements.

Performed analysis clearly showed significant differences concerning the quantity of chemical compounds in the S. vulgaris extracts obtained from leaves, bark, fruit, and flowers. Important amounts of free or glycosylated chemical components belonging to various therapeutically important structural classes, such as phenyl-propanoids (syringin, acteoside, echinacoside), flavonoids (quercetin and kaempferol derivatives), secoiridoids (secologanoside, oleuropein, 10-hydroxy oleuropein, demethyloleuropein, syringalactone A, nuzhenide, lingstroside) and p-coumaroyl-glycolic acid were obtained. Twelve out of 14 identified compounds were detected and quantified for in all tested extracts, while acteoside and oleuropein were not found in the fruit extract (Table 1). Furthermore, significantly high amounts of certain identified compounds, namely p-coumaroyl-glicolic acid $(6748.16 \mu \mathrm{g} / \mathrm{g})$, secologanoside $(27,663.00 \mu \mathrm{g} / \mathrm{g})$, acteoside $(9408.78 \mu \mathrm{g} / \mathrm{g})$, quercetinrutinoside $(7642.07 \mu \mathrm{g} / \mathrm{g})$, demethyl oleuropein $(35,729.89 \mu \mathrm{g} / \mathrm{g})$, kaempferol-glucoside $(3814.93 \mu \mathrm{g} / \mathrm{g})$, nuzhenide $(15,893.68 \mu \mathrm{g} / \mathrm{g})$ were observed in the case of the flower extract (Table 1). Nuzhenide is a secoiridoidic compound with strong antioxidant activity, similar oleuropein and its derivatives $[4,10]$.

The bark extract possessed the highest concentration in syringin $(74,535.30 \mu \mathrm{g} / \mathrm{g})$, syringalactone $\mathrm{A}(17,161.82 \mu \mathrm{g} / \mathrm{g}), \mathbf{1 0}$-Hydroxy-oleuropein $(8943.89 \mu \mathrm{g} / \mathrm{g})$, echinacoside $(38,299.52 \mu \mathrm{g} / \mathrm{g})$, ligstroside $(24,820.71 \mu \mathrm{g} / \mathrm{g})$, oleuropein $(9139.07 \mu \mathrm{g} / \mathrm{g})$, oleuropeinaglycone $(42,796.39 \mu \mathrm{g} / \mathrm{g})$ (Table 1$)$. These results underlined bark extract rich content in echinacoside, a phenylpropanoid glycoside recognized for immunostimulant and antioxidant properties, and syringin, a phenylpropanoid glycoside with immunostimulatory, antioxidant and antidiabetic properties [17]. Moreover the bark syringin presence was also highlighted in the other analyzed parts of the plant $(14,653.98 \mu \mathrm{g} / \mathrm{g}$ for flowers extract, $9245.97 \mu \mathrm{g} / \mathrm{g}$ for leaves extract).

Overall, flowers extract revealed the highest and most balanced content of phenylpropanoid, flavonoid and secoiridoid compounds, while the fruit extract presented the lowest content of these active compounds. 
Although literature does not document detailed information regarding the chemical profile of ethanolic extracts, the polyphenolic composition was assessed in the case of extracts obtained from lilac flowers [10,15], fruit [10], bark [11,14] and leaves [11,15,18]. Tóth et al. performed the HPLC-DAD-ESI-MS analysis of methanolic extracts obtained from lilac flowers and fruit and indicated 34 compounds, including 18 secoiridoids, seven phenylpropanoids, four flavonoids and five low molecular weight phenols. Flowers were found to contain significant amounts of phenylpropanoids (acteoside, 2.48\%; echinacoside, $0.75 \%$ ) and oleuropein $(0.95 \%)$, while the fruit's major secondary metabolites were identified as secoiridoids oleuropein (1.09\%) and nuzhenide (0.42\%) [10]. Another study pointed out a complex metabolite profile and the antioxidant potential in the case of Syringa vulgaris bark and leaf methanolic extracts. A total of 33 compounds (15 secoiridoids, 6 phenylpropanoids, 3 flavonoids, 3 lignans and 6 low molecular weight phenols) were identified by HPLC-DAD-ESI-TOF and HPLC-DAD-ESI-MS/MS. The main phenolic compounds in bark and leaves were represented by syringin $(2.52 \%)$ and rutin $(1.13 \%)$ respectively [11]. Filipek et al. reported the identification of 22 compounds: five simple phenolic compounds, four lignans, three phenylethanoids, a phenylethanoid esterified with an oleoside and eight secoiridoids and iridoids. Among these compounds, syringin, acteoside, nuzhenide, echinacoside, oleuropein, and ligstroside were the most important [14].

Taking all of this into consideration, the present study brings novelty and originality, being, to the best of our knowledge, the only one comparing the four different extracts (obtained from flowers, leaves, bark and fruit), reporting large amounts of bioactive compounds in their composition and showing therefore that flowers represent the most important source of active principles.

\subsection{Vibrational IR Spectra of Syringa vulgaris L., Bark and Fruit Extracts}

Infrared spectroscopy is an effective and non-targeted analytical method which could non-destructively and cost-effectively detect the intrinsic quality of different plants $[19,20]$. Based on FT-IR results, it is possible to highlight a list of peaks that can be assigned to different biochemical class of compounds, which could lead to a better correlation between the chemical structure and the spectroscopic features of plants [21]. Therefore, this technique also provides a precise assignment of the functional groups, bonding types and molecular conformations within plant tissue and cells [20].

The FT-IR spectra of analyzed $S$. vulgaris extracts showed some spectral changes (Figure 1). Moreover, as it can be observed in Tables 1 and 2, the main functional groups of echinacoside (a phenyl-propanoid), rutin (a flavonoid) and iridoids were illustrated in the FT-IR spectra of $S$. vulgaris extracts. Thus, peaks between $814-816 \mathrm{~cm}^{-1}, 1513-1515 \mathrm{~cm}^{-1}$ were characteristic to phenyl-propanoid-associated signals of echinacoside [21,22]. Within a similar range, terpene-associated stretching vibrations of $\mathrm{C}=\mathrm{O}$ had contribution to band from 1694-1702 $\mathrm{cm}^{-1}$ [23]. Another terpene-associated peak was observed in the range 2901-2909 $\mathrm{cm}^{-1}$ and was caused by the C-H stretching vibration [20,23-25]. Furthermore, the peaks found between $885-890 \mathrm{~cm}^{-1}$ and $2925-2933 \mathrm{~cm}^{-1}$ were associated with the presence of $\mathrm{CH}_{2}$ functional group, while the peak between $1256-1268 \mathrm{~cm}^{-1}$ could be attributed to $\mathrm{C}-\mathrm{O}$ stretching vibration from both terpene and iridoids [23]. A strong peak in the range $1076-1079 \mathrm{~cm}^{-1}$ was caused by iridoids stretching vibration of $-\mathrm{C}-\mathrm{OH}$ [24-26]. Presence of flavonols in the $S$. vulgaris analyzed extracts could also be confirmed. Therefore, the peak occurring within range $1596-1608 \mathrm{~cm}^{-1}$ could be attributed to $C=C$ stretching vibrations from the structure of both flavonols and iridoids [24,26-28]. Similarly, in the FT-IR spectra of $S$. vulgaris analyzed extracts, flavonols possess $\mathrm{C}-\mathrm{O}-\mathrm{C}, \mathrm{C}=\mathrm{C}$ and $\mathrm{CH}_{3}$ functional groups which display peaks between $924-930 \mathrm{~cm}^{-1}, 1159-1162 \mathrm{~cm}^{-1}$ and $1385-1404 \mathrm{~cm}^{-1}$ respectively [20,23,27-29] (Tables 2 and 3). 

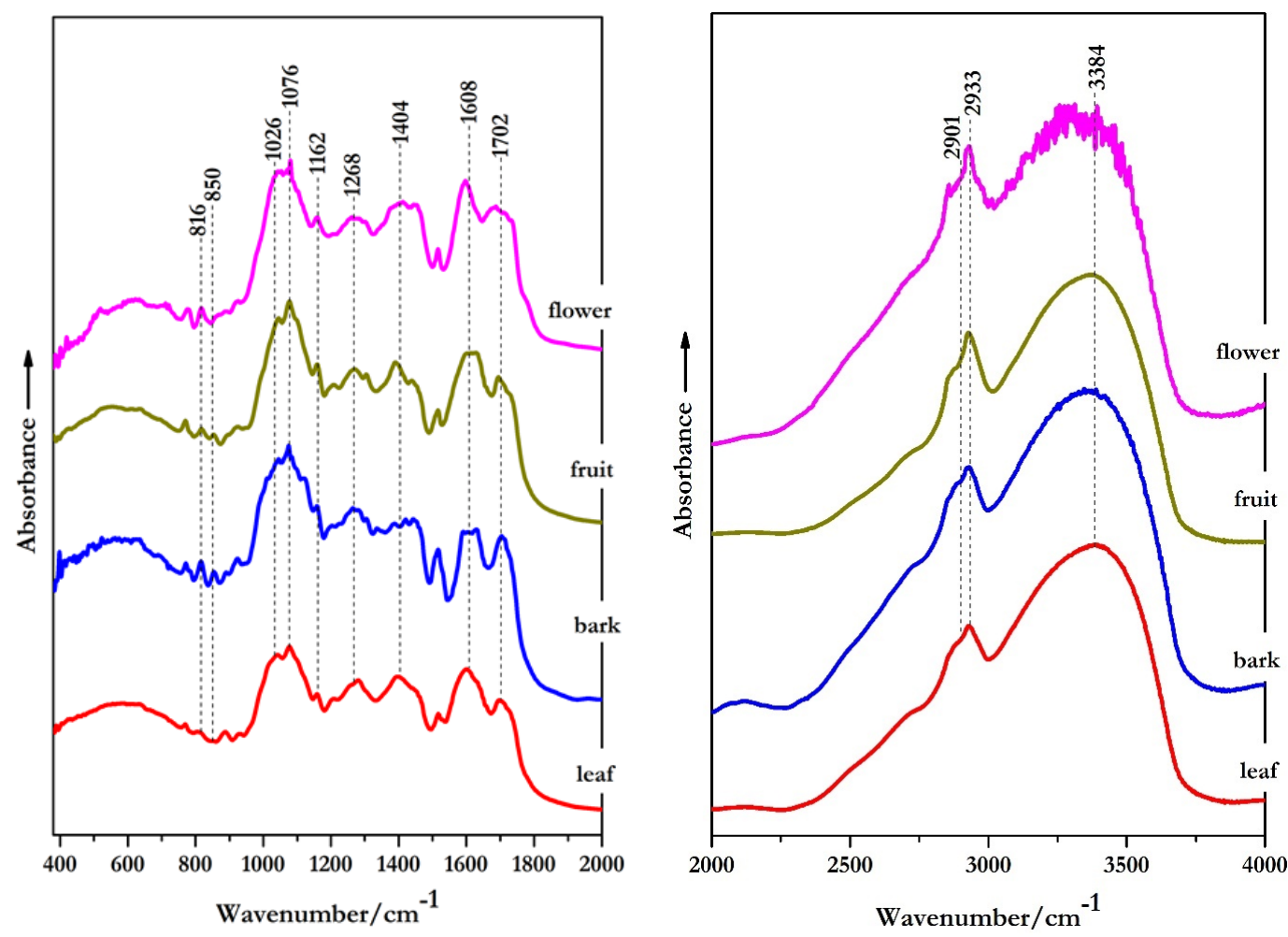

Figure 1. The FT-IR absorbance spectra of $S$. vulgaris flowers, bark, leaves and fruit extracts. The profiles are presented in the wavenumber range $400-2000 \mathrm{~cm}^{-1}$ (left) and $2000-4000 \mathrm{~cm}^{-1}$ (right).

Table 2. Peak positions $\left(\mathrm{cm}^{-1}\right)$ and tentative assignments of FT-IR absorbance bands for S. vulgaris extracts from the leaves, bark, flowers and fruit recorded in the spectral region from 400 to $2000 \mathrm{~cm}^{-1}$.

\begin{tabular}{|c|c|c|c|c|c|}
\hline $\begin{array}{l}\text { S. vulgaris } \\
\text { Leaves }\end{array}$ & $\begin{array}{l}\text { S. vulgaris } \\
\text { Bark }\end{array}$ & $\begin{array}{l}\text { S. vulgaris } \\
\text { Fruit }\end{array}$ & $\begin{array}{l}\text { S. vulgaris } \\
\text { Flowers }\end{array}$ & Tentative Assignement & References \\
\hline$\sim 605$ & $\sim 605$ & $\sim 593$ & $\sim 598$ & $\beta(\mathrm{CH})$ & {$[20,30]$} \\
\hline$\sim 704$ & $\sim 704$ & $\sim 704$ & $\sim 705$ & $\gamma(\mathrm{C}=\mathrm{O})$ & [30] \\
\hline$\sim 766$ & $\sim 766$ & $\sim 766$ & $\sim 774$ & $\mathrm{C}-\mathrm{O}-\mathrm{C}$ ring vibration & [29] \\
\hline$\sim 816$ & $\sim 816$ & $\sim 816$ & $\sim 814$ & $\begin{array}{l}\text { Phenyl-propanoid-associated } \\
\text { signals of echinacoside }\end{array}$ & {$[21,22]$} \\
\hline- & $\sim 853$ & $\sim 853$ & - & $\gamma(\mathrm{CH}) \mathrm{ar}$ & [30] \\
\hline$\sim 885$ & $\sim 890$ & $\sim 890$ & $\sim 884$ & $\begin{array}{c}-\mathrm{CH}_{2} \text { out-of-plane deformation } \\
\text { (Terpene) }\end{array}$ & [23] \\
\hline$\sim 930$ & $\sim 925$ & $\sim 925$ & $\sim 924$ & $\begin{array}{l}\text { C-O-C ring vibration } \\
\text { Symmetric stretching } \\
\text { Rutin }\end{array}$ & [27-29] \\
\hline$\sim 1026$ & $\sim 1033$ & $\sim 1032$ & $\sim 1039$ & $-\mathrm{C}-\mathrm{O}, \mathrm{C}-\mathrm{O}-\mathrm{H}, \mathrm{C}-\mathrm{O}-\mathrm{C}, \mathrm{C}-\mathrm{C}$ & [20] \\
\hline$\sim 1076$ & $\sim 1076$ & $\sim 1076$ & $\sim 1079$ & $\begin{array}{l}\text {-C-OH stretching } \\
\text { (iridoids skeletal vibration) }\end{array}$ & {$[24-26]$} \\
\hline- & $\sim 1106$ & - & - & C-O stretch & {$[23,28]$} \\
\hline 1162 & 1162 & 1162 & 1159 & $\begin{array}{c}\mathrm{C}=\mathrm{C} \text { Stretching } \\
\text { Rutin }\end{array}$ & {$[27,28]$} \\
\hline$\sim 1268$ & $\sim 1261$ & $\sim 1256$ & $\sim 1263$ & $\begin{array}{l}\text { C-O stretching } \\
\text { (due to to terpenes, phenols or } \\
\text { carbohydrates from iridoids) }\end{array}$ & {$[20,24,25]$} \\
\hline$\sim 1404$ & $\sim 1385$ & $\sim 1394$ & $\sim 1401$ & $\begin{array}{c}\text { symmetrical } \mathrm{CH}_{3} \text { deformation } \\
\text { Rutin }\end{array}$ & {$[20,23,27,28]$} \\
\hline$\sim 1454$ & $\sim 1454$ & $\sim 1443$ & $\sim 1454$ & $\begin{array}{l}\text { C-H asymmetric bending } \\
\text { (esters, carbohydrate) }\end{array}$ & [25] \\
\hline 1515 & 1515 & 1515 & $\sim 1516$ & $\begin{array}{l}\text { Phenyl-propanoid-associated } \\
\text { signals of echinacoside } \\
\text { C }=C \text { stretching }\end{array}$ & {$[21,22]$} \\
\hline 1608 & 1608 & 1608 & $\sim 1596$ & $\begin{array}{c}\text { Rutin } \\
\text { (iridoids skeletal vibration) }\end{array}$ & {$[24,26-28]$} \\
\hline$\sim 1702$ & $\sim 1702$ & $\sim 1696$ & $\sim 1694$ & $\begin{array}{l}\mathrm{C}=\mathrm{O} \text { stretch } \\
\text { (terpenoids) }\end{array}$ & [23] \\
\hline
\end{tabular}


Table 3. Peak positions $\left(\mathrm{cm}^{-1}\right)$ and tentative assignments of FT-IR absorbance bands for Syringa vulgaris extracts from the leaves, bark, flowers and fruit recorded in the spectral region from 2000 to $4000 \mathrm{~cm}^{-1}$.

\begin{tabular}{|c|c|c|c|c|c|}
\hline $\begin{array}{l}\text { S. vulgaris } \\
\text { Leaves }\end{array}$ & $\begin{array}{l}\text { S. vulgaris } \\
\text { Bark }\end{array}$ & $\begin{array}{l}\text { S. vulgaris } \\
\text { Fruit }\end{array}$ & $\begin{array}{l}\text { S. vulgaris } \\
\text { Flowers }\end{array}$ & Tentative Assignement & References \\
\hline 2901 & 2901 & 2909 & & $\begin{array}{l}\text { C-H stretch } \\
\text { (terpenoid) }\end{array}$ & [23] \\
\hline 2933 & 2925 & 2933 & & $\begin{array}{c}-\mathrm{CH}_{2} \text { asymmetric stretching } \\
\text { (from iridoids) }\end{array}$ & {$[20,24,25]$} \\
\hline$\sim 3384$ & $\sim 3376$ & $\sim 3376$ & & $\begin{array}{c}\text {-OH stretching vibration of } \\
\text { phenols, carboxylic acids and } \\
\text { alcohols }\end{array}$ & {$[20,27,28]$} \\
\hline
\end{tabular}

Another observation is that the bands in the region $1000-1800 \mathrm{~cm}^{-1}$ are of much higher intensity compared to the bands bellow $1000 \mathrm{~cm}^{-1}$. Additionally, in the same region one can observe that some bands are shifted to lower or higher wavenumbers.

\subsection{Quantification of Total Polyphenolic (TPC), Flavonoids (TFC) and Phenolic Acids Content (TPA)}

The total polyphenols, flavonoids, and phenolic acids content of the $S$. vulgaris tested extracts showed significant amounts of all these compounds that could be corroborated with the results obtained for the assessment of the biological activities (Table 4).

Table 4. Total polyphenols content of the S. vulgaris extracts.

\begin{tabular}{cccc}
\hline Sample & TPC $(\mathbf{m g}$ GAE/g) & TFC $(\mathbf{m g}$ RE/g) & TPA (mg CAE/g) \\
\hline bark & $3.36 \pm 0.42$ & $0.19 \pm 0.24$ & $3.99 \pm 0.84$ \\
leaves & $3.86 \pm 0.31$ & $0.71 \pm 0.41$ & $4.90 \pm 0.42$ \\
flowers & $3.98 \pm 0.28$ & $1.21 \pm 0.12$ & $2.36 \pm 0.06$ \\
fruit & $2.25 \pm 0.02$ & $0.75 \pm 0.01$ & $1.22 \pm 0.01$
\end{tabular}

Note: Values represent the mean \pm SD of three independent measurements. TPC $=$ total polyphenolic content $\mathrm{TFC}=$ total flavonoids content; TPA $=$ total phenolic acids content; $\mathrm{GAE}=$ gallic acid equivalents; $\mathrm{RE}=$ rutin equivalents; $\mathrm{CAE}=$ caffeic acid equivalents.

Quantification of TPC, TFC and TPA are reported hereby for the first time in scientific literature for the $S$. vulgaris species, representing a further reason that sustains the originality of this study and offering important arguments in order to support the biological activities that are tested.

\subsection{GC-MS Analysis}

Results obtained for the GC-MS analysis of different $S$. vulgaris extracts can be found in Tables $5-8$.

Table 5. The tentative identification of the main compounds in S. vulgaris flowers extract by GC-MS analysis.

\begin{tabular}{cccc}
\hline Identified Compound & Retention Time (min) & Area & Content $\%$ \\
\hline Benzyl alcohol & 6.52 & 472,069 & $27.36 \pm 0.19$ \\
Diethyl malonate & 6.80 & 26,382 & $1.53 \pm 1.29$ \\
5-ethoxydihydro-2-furanone & 6.88 & 72,759 & $4.22 \pm 0.95$ \\
3,4-dihydroxytetrahydro-2-furanone & 7.43 & 86,244 & $5.00 \pm 0.31$ \\
Lilac alcohol C & 8.86 & 132,859 & $7.70 \pm 1.02$ \\
Lilac alcohol D & 8.98 & 569,808 & $33.02 \pm 0.88$ \\
5-oxotetrahydrofuran-2 carboxylic acod, ethyl ester & 9.11 & 33,140 & $2.01 \pm 0.10$ \\
2-methyl-propanoic acid, propyl ester & 9.45 & 34,760 & $1.83 \pm 0.09$ \\
3-Phenylpropanal & 10.27 & 23,867 & $2.35 \pm 0.92$ \\
4-hydroxy-2-methylacetophenone & 10.41 & 40,576 & $3.72 \pm 0.37$ \\
Ethyl 3,3-diethoxypropionate & 10.44 & 64,276 & 16,343 \\
2-hydroxy-3-methylsuccinic acid & 10.51 & 10,896 & $0.95 \pm 0.41$ \\
Tetrahydro [2,2] bifuranyl-5-one & 10.59 & 23,664 & $0.63 \pm 0.56$ \\
4-hydroxy-benzaldehyde & 10.81 & 14,156 & $1.50 \pm 1.16$ \\
Methyleugenol & 11.50 & & $0.82 \pm 0.72$ \\
\hline
\end{tabular}


Table 5. Cont.

\begin{tabular}{cccc}
\hline Identified Compound & Retention Time (min) & Area & Content $\%$ \\
\hline p-hydroxycinnamic acid, ethyl ester & 15.39 & 15,797 & $0.92 \pm 0.19$ \\
Tetradecanoic acid, ethyl ester & 16.33 & 31,256 & $1.81 \pm 1.02$ \\
n-hexadecanoic acid & 18.66 & 38,934 & $2.26 \pm 0.94$ \\
11,14-eicosadienoic acid, methyl ester & 21.66 & 7722 & $0.45 \pm 0.01$ \\
\hline
\end{tabular}

Note: Values represent the mean $\pm \mathrm{SD}$ of three measurements.

Table 6. The tentative identification of the main compounds in S. vulgaris bark extract by GC-MS analysis.

\begin{tabular}{cccc}
\hline Identified Compound & Retention Time (min) & Area & Content $\%$ \\
\hline á-Psi-Carotene & 6.50 & 663.200 & $0.61 \pm 0.22$ \\
Benzoic acid, 4 formyl, methyl ester & 11.14 & $13,207.20$ & $12.20 \pm 0.79$ \\
2-metoxyphenol & 15.81 & 5445.60 & $5.03 \pm 0.64$ \\
n-Hexadecanoic acid & 18.66 & 8976.40 & $8.35 \pm 0.09$ \\
Astaxanthin & 19.31 & 1347.60 & $1.24 \pm 0.12$ \\
trans-Sinapyl alcohol & 19.42 & $15,466.00$ & $14.28 \pm 0.90$ \\
Oleic acid & 21.77 & $17,973.60$ & $16.06 \pm 0.02$ \\
\hline
\end{tabular}

Note: Values represent the mean \pm SD of three measurements.

Table 7. The tentative identification of the main compounds in S. vulgaris leaves extract by GC-MS analysis.

\begin{tabular}{cccc}
\hline Identified Compound & Retention Time (min) & Area & Content $\%$ \\
\hline Benzyl alcohol & 6.54 & 4403.200 & $3.26 \pm 0.75$ \\
Benzofuran,2,3-dihydro & 8.92 & 5456.000 & $4.05 \pm 0.95$ \\
Benzoic acid, 4-formyl, methyl ester & 11.15 & $10,302.400$ & $7.64 \pm 0.01$ \\
Benzaldehyde, 2-hydroxy-6-methyl & 11.94 & $12,287.600$ & $9.12 \pm 0.56$ \\
á-Phellandrene & 13.15 & 1151.200 & $0.85 \pm 0.22$ \\
4-\{(1E)-3-Hydroxy-1-propenyl)-2-metoxyphenol & 15.82 & 5185.200 & $3.85 \pm 0.33$ \\
n-Hexadecanoic acid & 16.67 & 5146.400 & $3.83 \pm 0.57$ \\
\hline
\end{tabular}

Note: Values represent the mean $\pm \mathrm{SD}$ of three measurements.

Table 8. The tentative identification of the main compounds in S. vulgaris fruit extract by GC-MS analysis.

\begin{tabular}{cccc}
\hline Identified Compound & Retention Time (min) & Area & Content $\%$ \\
\hline n-Hexadecanoic acid & 18.67 & $17,880.400$ & $11.83 \pm 0.06$ \\
trans-13-octadecenoic acid & 21.60 & 6479.200 & $4.28 \pm 0.09$ \\
Trans-13-octadecanoic acid & 21.77 & $32,274.00$ & $21.36 \pm 0.22$ \\
Oleic acid & 21.85 & 8079.60 & $5.35 \pm 0.25$ \\
Octadecanoic acid & 22.18 & $12,766.80$ & $8.45 \pm 0.36$ \\
\hline
\end{tabular}

Note: Values represent the mean $\pm \mathrm{SD}$ of three measurements.

The GC-MS analysis allowed to identify the main volatile compounds in the S. vulgaris flowers extract that are the two steroisomers of the lilac alcohols, lilac alcohol $\mathrm{C}$ and lilac alcohol D. Together with these, other aromatic compounds, phenols and acids, fatty acids could be identified in the composition of the flowers (Table 5).

Twenty compounds were identified and among these the ones that were found in the highest amounts are the lilac alcohols and the benzyl alcohol, with matching factors higher than 80. Furane derivatives were also identified in high amounts, being related to lilac alcohols. The specific compounds, lilac alcohols, as furane alcohols, represented more than $40 \%$ of the identified compounds. The two compounds are two different stereoisomers with similar MS spectra (Figure 2) that corresponds with those of standard data from PubChem. They have a major signal at $m / z$ of 55 and other important signals at $m / z$ of 67,93 and 111 . 

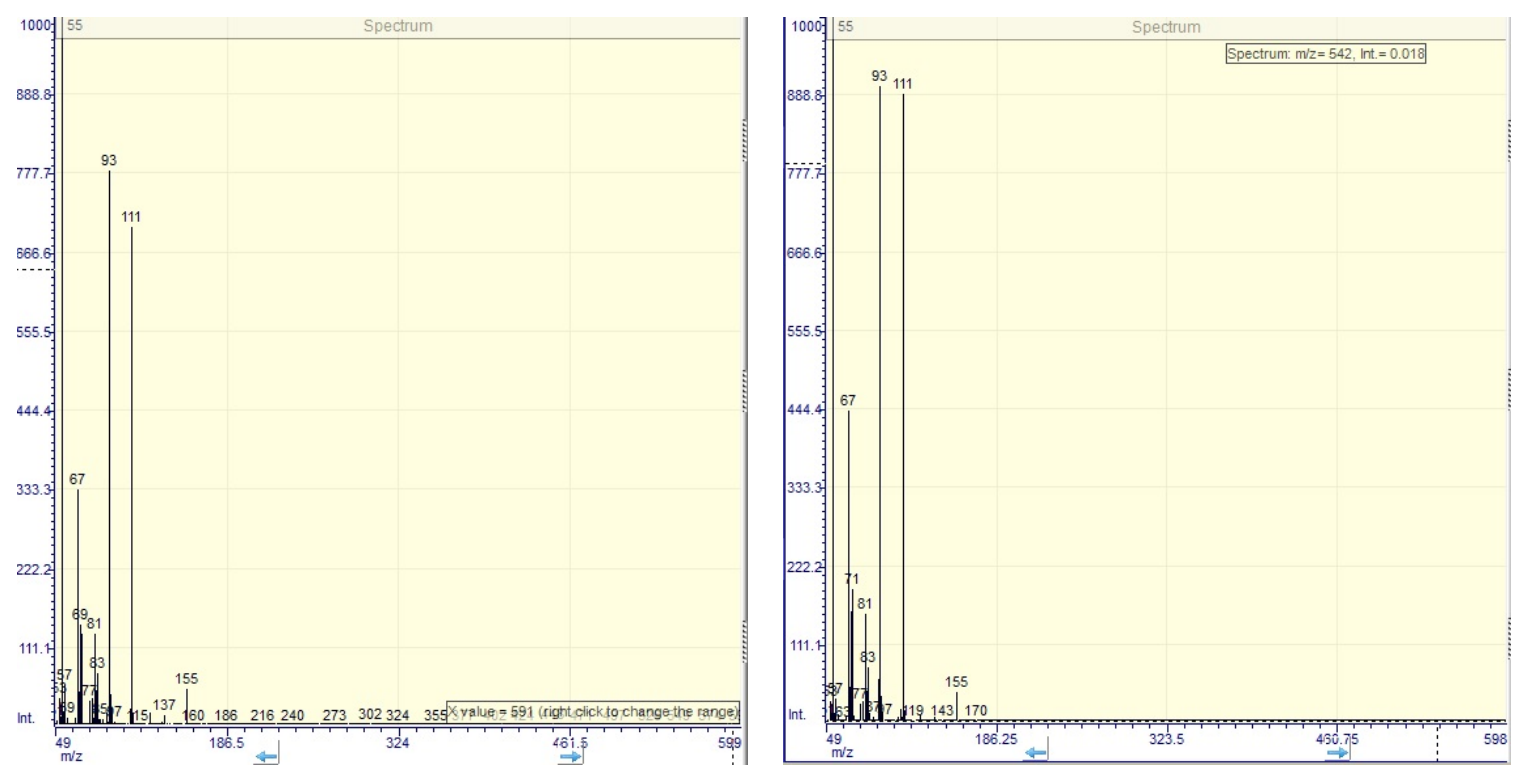

Figure 2. The MS spectra of lilac alcohol C (left) and D (right) separated from Syringa vulgaris flowers extract.

Together with lilac alcohols, another important compound that is responsible for the aromatic smell of lilac flowers is the benzyl alcohol, found in high amount $1.77 \%$ of the identified compounds are furane derivatives, compounds that are related to lilac alcohols.

Another compound that was identified in a significant amount is methyleugenol, a phenypropanoidic compound with important antioxidant activity. The phenolic compounds percentage is at $1.74 \%$ and they are being represented, moreover methyleugenol, by the ester of p-hydroxycinnamic acid fatty acid esters and free fatty acids were also identified that represents $4.52 \%$ of the identified compounds.

For the other tested extracts, GC-MS analysis was performed in the same conditions and different compounds were identified (Tables 6-8). The common compound identified in all these extracts is the n-hexadecanoic acid, a saturated fatty acid, named also palmitic acid. The fruit extract is rich in fatty acids, the main being the trans-13-octadecanoic acid. The leaves extract contains benzoic acid derivatives and also phellandrene. The bark extract contains carotenes: astaxanthin and psi-carotene respectively more than $12 \%$ trans-sinapyl alcohol.

The GC-MS analysis of these extracts is reported hereby for the first time, representing an important tool for the identification of the main compounds found in the composition of different extracts obtained from different parts of the species that are responsible for the biological activities.

\subsection{Antioxidant Activity Assays}

The in vitro antioxidant capacity of $S$. vulgaris extracts was evaluated by three different methods: 2,2-diphenyl-picrylhydrazil (DPPH•) scavenging assay, ferric-reducing antioxidant power (FRAP) and cupric ion reducing antioxidant capacity (CUPRAC) (Table 9). The three used methods were chosen in order to bring arguments that prove the antioxidant capacity of tested samples by three different mechanisms [31-33].

Table 9. Antioxidant activity of $S$. vulgaris extracts by different assays.

\begin{tabular}{cccc}
\hline Sample & DPPH $\left(\right.$ IC $\left._{\mathbf{5 0}} \boldsymbol{\mu g} / \mathbf{m L}\right)$ & FRAP $(\mu \mathbf{M}$ TE/g) & CUPRAC $(\mu M$ TE/g) \\
\hline bark & $956 \pm 1.71$ & $157.92 \pm 1.74$ & $279.4 \pm 1.18$ \\
leaves & $865 \pm 1.10$ & $178.92 \pm 0.62$ & $169.7 \pm 0.73$ \\
flowers & $36.83 \pm 0.47^{*}$ & $182.52 \pm 0.99^{*}$ & $329.3 \pm 0.15^{*}$ \\
fruit & $103.19 \pm 1.02$ & $116.85 \pm 0.42$ & $110.5 \pm 1.04$
\end{tabular}

Note: Values represent the mean $\pm \mathrm{SD}$ of three independent measurements. ${ }^{*} p<0.001$. 
Antioxidant activity for the flowers and fruit of S. vulgaris are reported by Tóth et al., using the DPPH bleaching assay and revealed an effective antioxidant activity of these methanolic extracts with $\mathrm{IC}_{50}=65.25 \mu \mathrm{g} / \mathrm{mL}$ and $\mathrm{IC}_{50}=67.39 \mu \mathrm{g} / \mathrm{mL}$, respectively [10] The same assay is used by Varga et al. and showed a superior antioxidant activity of leaves and bark extracts ( $\mathrm{IC}_{50}=25.25 \mu \mathrm{g} / \mathrm{mL}, \mathrm{IC}_{50}=40.61 \mu \mathrm{g} / \mathrm{mL}$ respectively) [11]. Our study revealed that the flowers extract showed significant $(p<0.001)$ higher antioxidant activity $\left(\mathrm{IC}_{50}=36.83 \mu \mathrm{g} / \mathrm{mL}\right)$ compared to the other analyzed extracts in the following order: flowers $>$ leaves $>$ bark $>$ fruit (Table 9). The similar results for flowers extract were obtained by CUPRAC and FRAP assays $(p<0.001)$. Moreover, the present study brings originality by offering, for the first time, proof of antioxidant capacity of the tested samples by different other mechanisms that are highlighted using the two other assays, FRAP and CUPRAC. At the same time, the study offers for the first time a comparative view on flowers, fruit, leaves and bark, bringing evidence on the fact that flowers represent the most important antioxidant potential.

Moreover the originality that is brought by the performed assays, the study of the antioxidant capacity of the tested samples becomes even more important, as it represents the basis of the cytotoxic activity. The antioxidant capacity is highly related to the phenolic composition of the tested samples [10,11], as it is largely known and accepted that phenylpropanoids, flavonoids and also secoiridoids exhibit antioxidant and antiproliferative capacity [34-36], but moreover, the antioxidant capacity can be, at the same time, highly related to the cytotoxic activity of these samples, as the antioxidant activity may represent one of the most important mechanisms at the basis of the cytotoxicity [37].

\subsection{Cytotoxiciy Assays}

To investigate the in vitro antiproliferative potential of the four S. vulgaris ethanolic extracts on two human cancer cell lines, HeLa and B16F10, the MTT assay was conducted. Results are presented in Figures 3 and 4.

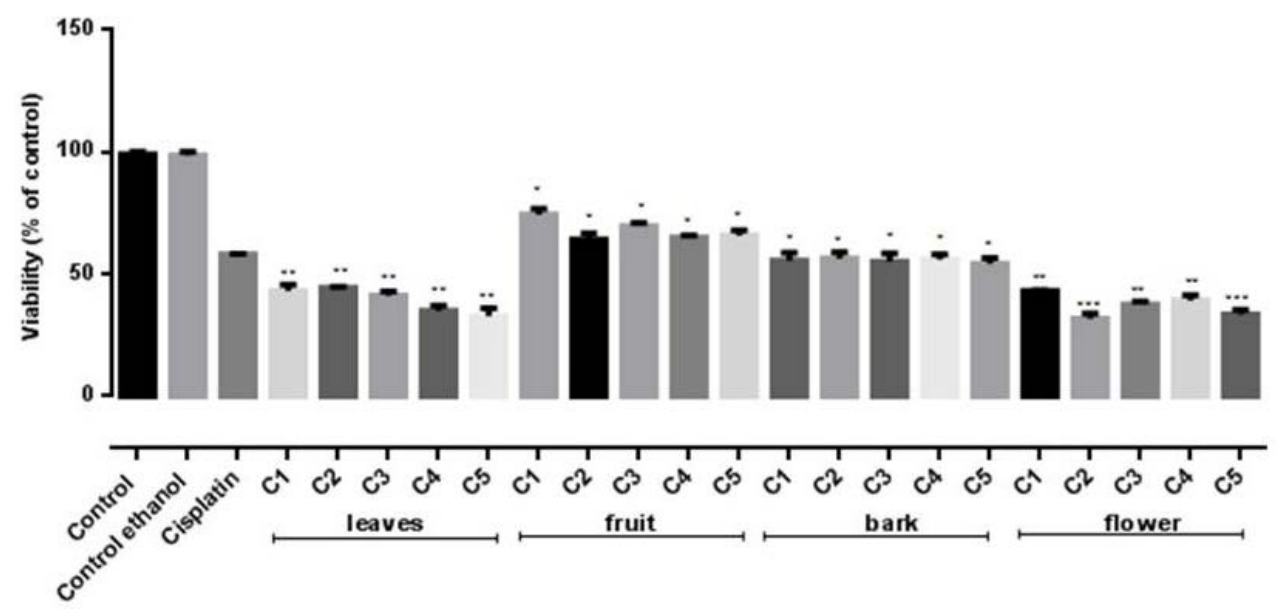

Figure 3. Inhibitory effects on Hela cell line of S. vulgaris leaves, fruit, bark and flowers extracts at five different concentrations C1-C5 calculated according to the TPC ( $\mu \mathrm{mol} \mathrm{GAE} / \mathrm{mL})$ determined for each extracts: leaves $(11.34-56.7 \mu \mathrm{mol} \mathrm{GAE} / \mathrm{mL})$, fruit (6.66-33.2 $\mu \mathrm{mol}$ GAE/mL), bark (9.875-49.37 $\mu \mathrm{mol} \mathrm{GAE/mL)} \mathrm{and} \mathrm{flowers} \mathrm{(11.69-58.475} \mathrm{\mu mol} \mathrm{GAE/mL);} \mathrm{Negative}$ control-untreated cells, Internal control—Ethanol, Positive control—Cisplatin. Values represent the mean \pm SD of three determinations. ${ }^{*} p<0.05 ;{ }^{* *} p<0.001 ;{ }^{* * *} p<0.0001$ (Differences between extract-treated cells and the negative control).

The performed analysis indicated a relevant in vitro cytotoxic activity for all tested extracts and differences in regard to the tested doses and cancer cell lines. The most intense in vitro cytotoxicity was noticed in the case of the flowers, followed by leaves and bark extracts, respectively. 


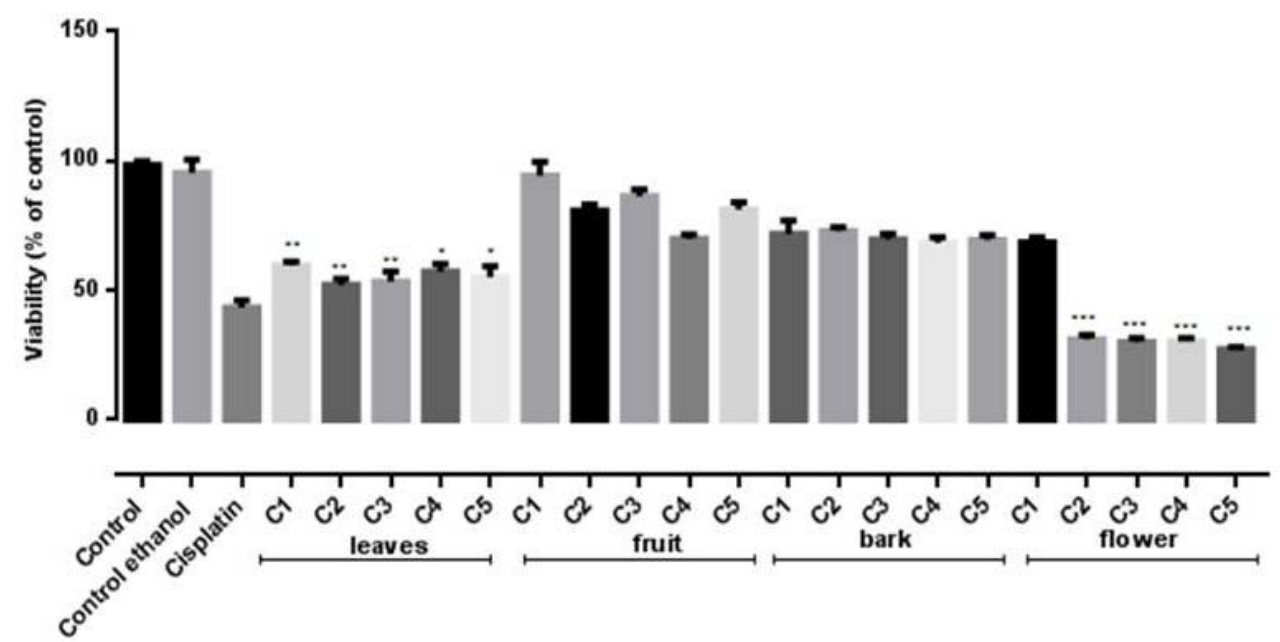

Figure 4. Inhibitory effects on B16H10 cell line of $S$. vulgaris leaves, fruit, bark and flowers extracts at five different concentrations C1-C5 calculated according to the TPC ( $\mu$ mol GAE/mL) determined for each extracts: leaves (11.34-56.7 $\mu \mathrm{mol} \mathrm{GAE/mL),} \mathrm{fruit} \mathrm{(6.66-33.2} \mu \mathrm{mol} \mathrm{GAE/mL),} \mathrm{bark} \mathrm{(9.875-49.37} \mu \mathrm{mol} \mathrm{GAE/mL)} \mathrm{and} \mathrm{flowers}$ (11.69-58.475 $\mu \mathrm{mol} \mathrm{GAE} / \mathrm{mL})$; Negative control—untreated cells, Internal control—Ethanol, Positive control—Cisplatin. Values represent the mean $\pm \mathrm{SD}$ of three determinations. ${ }^{*} p<0.05 ;{ }^{* *} p<0.001 ;{ }^{* *} p<0.0001$ (Differences between extract-treated cells and the negative control).

The flowers ethanolic extract displayed significant cytotoxic activity on both B16F10 and HeLa cells (Figures 3 and 4). The viability of both melanoma and carcinoma cells was significantly decreased $(p<0.0001)$ compared to the untreated control for concentrations of 23.39-58.475 $\mu \mathrm{mol} \mathrm{GAE/mL}$ and 11.69-58.475 $\mu \mathrm{mol}$ GAE/mL, respectively. No statistically significant $(p>0.05)$ differences between the viability values determined by these concentrations were noticed, indicating that the cytotoxic activity is not dose dependent. Similar to the flowers extract, the leaves extract showed significant cytotoxic effect on both cell lines $(p<0.001)$. Furthermore, when tested against HeLa cell line, these two extracts' inhibitory activity was comparable to the positive control-Cisplatin treated cells (Figure 3). On the B16F10 cells, a similar efficacy was displayed only by the flower extract, while the leaf and bark extracts possessed a lower cytotoxic effect compared to Cisplatin. The fruit extract proved the lowest cytotoxic effect (Figure 4).

Thus, our results demonstrate the in vitro cytotoxic properties of $S$. vulgaris extracts on two tumoral cell lines. HeLa cell line proved to be more susceptible than B16F10 cells; varying in vitro and in vivo sensitivity between differing tumor cell types is documented by literature $[38,39]$.

A non-linear regression analysis of the dose-response curve determined half maximal inhibitory concentration $\left(\mathrm{IC}_{50}\right)$ values for cytotoxic activity and the results are described in Table 10.

Table 10. In vitro antiproliferative activity of $S$. vulgaris ethanolic extracts expressed as half maximal inhibitory concentration $\left(\mathrm{IC}_{50}\right)(\mu \mathrm{mol} \mathrm{GAE} / \mathrm{mL})$ against B16F10 cells and HeLa cell lines.

\begin{tabular}{ccc}
\hline IC $_{\mathbf{5 0}}$ & B16F10 & HeLa \\
\hline Flower & $5.74 \pm 0.20$ & $5.13 \pm 0.12$ \\
Leaves & $3.08 \pm 0.23$ & $4.91 \pm 0.25$ \\
Fruit & $2.28 \pm 0.6$ & $2.74 \pm 0.4$ \\
Bark & $2.62 \pm 0.09$ & $3.32 \pm 0.09$ \\
& Standard: Cisplatin $0.2 \mu \mathrm{M} / \mathrm{mL}$ & \\
\hline
\end{tabular}

Note: Values represent the mean \pm SD of three independent measurements.

These results indicate that the lowest $\mathrm{IC}_{50}$ values in the case of $S$. vulgaris ethanolic extracts were obtained for fruit and bark, respectively. However, these values are calculated 
according to the TPC ( $\mu \mathrm{mol}$ GAE/mL) determined for each extract. Thus, considering the complex chemical composition established for all four extracts, correlations between the in vitro antiproliferative activity and identified groups and/compounds were determined. No correlation was found between cell viability with TPC $\left(\mathrm{r}^{2}=-0.4\right)$. A strong correlation was noticed between the inhibitory effect on cell viability and certain identified and quantified compounds that are described in Table 1 . The highest quantity of the following compounds 1, 2, 5, 7, 9, 11, 13 and 14 was attributed to the flowers extract chemical composition, while the rest of the compounds were the most aboundant in the bark extract (Table 1). Among these compounds, acteoside and echinacoside quantities appeared to strongly correlate with the cytotoxicity displayed by both flower $\left(\mathrm{r}^{2}=0.84-0.97\right.$ and $0.87-0.99$, respectively) and bark ( $\mathrm{r}^{2}=0.87-0.94$ and $0.85-0.99$, respectively) extracts toward $\mathrm{B} 16 \mathrm{H} 10$ cell line. In the case of HeLa cell line, the correlation was observed for ligstroside $\left(r^{2}=0.89-0.99\right)$, syringalactone $A\left(r^{2}=0.90-0.99\right)$ and oleuropein-aglycone $\left(r^{2}=0.95-0.98\right)$. Although all these three secoiridoids compounds were found at the highest quantity in the case of the bark extract, correlation coefficients between their contents in the bark extracts and antiproliferative activity were relatively low $\left(\mathrm{r}^{2}=-0.80-0.49\right)$.

These findings underline phenyl-propanoids (acteoside and echinacoside) and secoiridoids (ligstroside, syringalactone A, oleuropein-aglycone) among the compounds responsible for the $S$. vulgaris ethanolic flower extract antiproliferative efficacy toward B16H10 and HeLa cell line, respectively. These results are in agreement with previous reports demonstrating in vitro antiproliferative efficacy of secoiridoids [4].

Previous studies pointed out antioxidant and antitumor potential in the case of several Syringa species, suggesting these properties might be related to certain major identified compounds, namely iridoids and lignans $[4,5]$. Aqueous extracts obtained from flowers and leaves of S. pubescens were in vitro cytotoxic when tested against L2215 cell line, while S. patula floral buds extract and two isolated compounds, syringaresinol and oleoside 11-methyl ester, were able to inhibit HepG2 cells proliferation [4,5]. Similarly, oleuropein and 3, 4-dihydroxyphenylethyl alcohol 8-O- $\beta$-D-glucopyranoside, two compounds isolated from S. pubescens subsp. patula, expressed cytotoxicity against P-388, L-1210, SNU-5 and HL-60 cells [5].

Several compounds isolated from S. vulgaris leaves were reported to exhibit antitumoral potential $[4,40]$. Relatively weak cytotoxicity was highlighted in the case of isooleoacteoside and syringopicroside B when tested against LOX-IMVI melanoma cell line and NCI-H522 lung cancer cell line, respectively $[4,18]$. Additionally, the hydrolysis product of isooleuropein, displayed moderate cytotoxic activity against lung cancer cell lines DMS273 and DMS114 [4,40].

With all these in view and corroborating the results obtained in the phytochemical analysis, in the citotoxicity assays and in the antioxidant assays, the link between all these becomes obvious and it can be concluded that the antiproliferative activity of the tested samples is significant and may be due to an antioxidant mechanism. To the best of our knowledge, this is the first study aimed to evaluate and compare the chemical profile, antioxidative and antiproliferative properties of ethanolic extracts obtained from flowers, leaves, bark, and fruit of S. vulgaris.

\section{Materials and Methods}

\subsection{Chemicals and Reagents}

Acetonitrile for the HPLC-DAD-MS analysis was purchased by Merck (Darmstadt, Germany), while water was purified with a Direct-Q UV system by Millipore (Darmstadt, Germany). Chlorogenic acid, rutin and oleuropein (analytical purity) were purchased from Sigma Aldrich (Darmstadt, Germany). All other chemicals used were purchased from Alfa-Aesar, Karlsruhe, Germany. The cytotoxicity was tested on two tumoral cell lines: murine melanoma cells (B16F10 cells) and human cancer cell line (HeLa). The selected cell lines were obtained from American Type Cell Collection (ATCC) (Manassas, VA, USA). The B16F10 cells were maintained in RPMI 1640 medium (Sigma Aldrich, Darmstadt, Germany) 
supplemented with $10 \%$ fetal bovine serum (EuroClone, MI, Pero, Italy) and 1\% AntibioticAntimycotic $100 \times$ (Sigma Aldrich, Darmstadt, Germany). Hela cells were maintained in DMEM/F-12 medium (Gibco Life Technologies, Paisley, UK) supplemented with 10\% fetal bovine serum (EuroClone, MI, Pero, Italy) and 1\% Antibiotic-Antimycotic 100× (Sigma Aldrich, Darmstadt, Germany). The two cell lines were cultured in a $5 \% \mathrm{CO}_{2}$ incubator (Advantage-Lab, Schilde, Belgium) at $37^{\circ} \mathrm{C}$ in a humidified atmosphere. Cisplatin (Ebewe Pharma Ges.m.b. H. Nfg. KG, Unterach am Attersee, Austria) was included as standard positive control for cytotoxicity assay.

\subsection{Plant Material and Preparation of Extracts}

The vegetal material was harvested from Cluj county, North Western Romania. Flowers and leaves were harvested in April-May 2020, during flowering period of the species, while fruit and bark were harvested in September 2020. Voucher specimens for the harvested species are deposited in the herbarium of the Pharmacognosy Department of the Faculty of Pharmacy Cluj-Napoca (Voucher no83).

The harvested samples were air dried. For the obtention of extracts, grinded vegetal material of each sample were cold macerated with $70 \% v / v$ ethanol, in a ratio of 1:10. The solution was then subjected to percolation, filtered and used for the phytochemical analysis and biological activity testing of antioxidant capacity and cytotoxic activity [41].

\subsection{HPLC-DAD-ESI $I^{+}$Analysis of Polyphenolic Compounds}

Evaluation of polyphenolic compounds was performed on a HP-1200 liquid chromatograph, which was equipped with a quaternary pump, autosampler, DAD detector and MS-6110 single quadrupole API-electrospray detector (Agilent-Techonologies, Santa Clara, CA, USA). Detection of phenolic compounds was carried out in positive ionization mode. Different fragmentor, in the range 50-100 V, were applied. Separation of compounds was performed on a Eclipse XDB-C18 ( $5 \mu \mathrm{m} ; 4.5 \times 150 \mathrm{~mm}$ i.d.) column (Agilent), using as a mobile phase $0.1 \%$ acetic acid in water (A) and $0.1 \%$ acetic acid in acetonitrile (B). a multistep linear gradient was employed for elution, with the following composition: $5 \% \mathrm{~B}$ for $2 \mathrm{~min}$; from $5 \%$ to $90 \%$ of B in $20 \mathrm{~min}$, hold for $4 \mathrm{~min}$ at $90 \% \mathrm{~B}$, then $6 \mathrm{~min}$ to arrive at $5 \% \mathrm{~B}$. Flow rate was maintained at $0.5 \mathrm{~mL} / \mathrm{min}$ and temperature at $25 \pm 0.5^{\circ} \mathrm{C}$. The phenolic compounds in the extract were analyzed by comparing the retentions times, UV visible and mass spectra of each separated compound with three reference standards, as follows: for the flavonoids, compounds were quantified using the calibration curve of rutin obtained using five different concentrations, varying from 10 to $80 \mu \mathrm{g} / \mathrm{mL}$ and expressed as equivalents of rutin ( $\mathrm{mg}$ rutin/g plant material $\left(\mathrm{R}^{2}=0.9973\right)$ ), for phenyl-propanoids, the compounds were quantified using the calibration curve of chlorogenic acid obtained using five different concentrations, varying from 10 to $50 \mu \mathrm{g} / \mathrm{mL}$ and expressed as equivalents of chlorogenic acid/g plant material $\left(R^{2}=0.9937\right)$, while for iridoids the compounds were quantified using the calibration curve of oleuropein obtained using five different concentrations, varying from 10 to $100 \mu \mathrm{g} / \mathrm{mL}$ and expressed as equivalents of chlorogenic acid/g plant material $\left(R^{2}=0.9966\right)$. Positively charged ions were detected by mass spectrometry, using the Scan mode. The following conditions for mass spectrometry were used: gas temperature $3500 \mathrm{C}$, nitrogen flow $7 \mathrm{~L} / \mathrm{min}$, nebulizer pressure 35 psi, capillary voltage $3000 \mathrm{~V}$, fragmentor $100 \mathrm{~V}$ and $m / z 120-1200$. Chromatograms were recorded at $\lambda=280$ and $340 \mathrm{~nm}$. Data acquisition was performed using the Agilent ChemStation software [42,43].

\subsection{FT-IR Spectroscopy}

The Fourier Infrared transform spectroscopy was made at the Spectroscopy laboratory from Life Sciences Institute "King Michael I of Romania" from Cluj-Napoca. Prior to FT-IR analysis, the $S$. vulgaris leaf, flower, bark and fruit extracts were dried on a clean microscope slide for $12 \mathrm{~h}$ at room temperature. The dried extracts were then removed from the microscope slide and mixed with the $\mathrm{KBr}$ powder in a proportion of 1:100 and placed in spectral pellet press chamber steel kit. To form the translucent $\mathrm{KBr}$ pellet we 
applied a pressure of $10 \mathrm{t}$ for $2 \mathrm{~min}$. The FT-IR spectra were collected with a Jasco FT-IR 4100 spectrometer (Jasco, Germany), in the $4000-400 \mathrm{~cm}^{1}$ spectral range, using $256 \mathrm{scans} /$ sample at $4 \mathrm{~cm}^{-1}$ resolution. Furthermore, the obtained Ft-IR spectra were corrected for $\mathrm{CO}_{2}$ and $\mathrm{H}_{2} \mathrm{O}$ using the Spectra Manager program of the same used software. Finally, the FT-IR data analysis was carried out using OriginPro Version 8.5.1 software (OriginLab Corporation, Northampton, MA, USA).

\subsection{Quantification of Total Polyphenols, Flavonoids and Phenolic Acids Content}

Total phenolic content (TPC) was assessed by a spectrophotometric method based on the color reaction of polyphenols with the Folin-Ciocâlteu reagent, according to the European Pharmacopoeia, using a calibration curve of gallic acid $\left(R^{2}=0.9928\right)$. Results were expressed as mg gallic acid equivalents (GAE)/g dried vegetal material. Determination of total flavonoids (TFC) was also performed by a spectrophotometric, using the aluminum chloride method, based on a calibration curve of rutin $\left(R^{2}=0.9981\right)$ and expressing results as $\mathrm{mg}$ of rutoside equivalents (RE)/g dried vegetal material. Total phenolic acids (TPA) was assessed by a spectrophotometrical method, using Arnow's reagent, similar to the one existing in the 10th Edition of the Romanian Pharmacopoeia (Cynarae folium monograph). Results of the TPA determination were expressed as mg caffeic acid equivalents (CAE)/g dried vegetal material and calculated using a caffeic acid calibration curve graph $\left(R^{2}=0.9956\right)$. All these experiments were performed in triplicate $[31,33,44]$.

\subsection{GC-MS Analysis}

The GC-MS analysis was carried out on a Dani Master GC-MS System. A SH-Rxi-5 ms column with $30 \mathrm{~m} \times 0.25 \mathrm{~mm} \times 0.25 \mu \mathrm{m}$ was used for the separation of compounds. Nitrogen was used as carrier gas, with $10 \mathrm{~mL} / \mathrm{min}$ flow rate. The temperature of the system followed the gradient found in Table 11.

Table 11. GC-MS temperature gradient.

\begin{tabular}{ccc}
\hline Time & Temperature & Rate \\
\hline 0 min & $80{ }^{\circ} \mathrm{C}$ & $0{ }^{\circ} \mathrm{C} / \mathrm{min}$ \\
$7 \mathrm{~min}$ & $220^{\circ} \mathrm{C}$ & $20^{\circ} \mathrm{C} / \mathrm{min}$ \\
$11 \mathrm{~min}$ & $240^{\circ} \mathrm{C}$ & $5^{\circ} \mathrm{C} / \mathrm{min}$ \\
$24 \mathrm{~min}$ & $240^{\circ} \mathrm{C}$ & $0{ }^{\circ} \mathrm{C} / \mathrm{min}$ \\
\hline
\end{tabular}

Five $\mu \mathrm{L}$ of each sample, diluted 1 to 10 with absolute ethanol, were injected. The EIS-MS detector identified compounds with molecular weight from 50 to 600 daltons. The ion source was operated at $200^{\circ} \mathrm{C}$. The compounds were tentatively identified based on the matching factor, using the NIST MS 2.2 spectra database. A matching score higher than $80 \%$ was considered acceptable for identification of the compounds. Quantitative analysis was performed by area normalization method and the results were express as area percentage $(\%)[31,45]$.

\subsection{Antioxidant Activity Assays}

\subsubsection{DPPH Radical Scavenging Activity}

For assessing the antioxidant capacity of $S$. vulgaris extracts, the DPPH bleaching assay was used. It is a spectrophotometric method, based on the reaction of the DPPH• reagent and antioxidants that are present in tested extracts $\mathrm{mL}$ of each extract of different concentrations were added to $2 \mathrm{~mL} 0.1 \mathrm{~g} / \mathrm{L} \mathrm{DPPH} \bullet$ methanolic solution and maintained at $40{ }^{\circ} \mathrm{C}$ in a thermostatized bath, for half an hour. Absorbance and their variation were measured at $517 \mathrm{~nm}$. Inhibition of the DPPH• radical was calculated using the formula: DPPH scavenging ability $\%=\left(A_{\text {control }}-A_{\text {sample }} / A_{\text {control }}\right) \times 100$, where $A_{\text {control }}$ is the absorbance of control, composed of the DPPH $\bullet$ radical solution + methanol (a mixture containing all reagents except the tincture) and $\mathrm{A}_{\text {sample }}$ is the absorbance of DPPH radical + samples. Percentage of DPPH decrease was expressed in Trolox equivalents $\left(T E, \mathrm{R}^{2}=0.987\right)$. 
DPPH radical scavenging activity of the tincture was expressed as $\mathrm{IC}_{50}(\mu \mathrm{g} / \mathrm{mL})$. Assays were performed in triplicate $[32,33,46]$.

\subsubsection{Ferric-Reducing Antioxidant Power Assay (FRAP)}

The FRAP method is a spectrophotometric method based on the color change of a 2,4,6-tri(2-pyridyl)-1,3,5-triazine (TPTZ) radical complex with $\mathrm{Fe}^{3+}$. This color change is assessed by the reduction of the ferric ion $\left(\mathrm{Fe}^{3+}\right)$ to the ferrous ion $\left(\mathrm{Fe}^{2+}\right)$ in this complex [47]. The FRAP reagent consists of a mixture of $2.5 \mathrm{~mL}$ of a $10 \mathrm{mM}$ TPTZ solution in $40 \mathrm{mM} \mathrm{HCl}$, mixed with $2.5 \mathrm{~mL} 20 \mathrm{mM}$ ferric chloride solution and $25 \mathrm{~mL}$ of acetate buffer at $\mathrm{pH}=3.6$. Of each tested sample, $4 \mathrm{~mL}$ was diluted to $1.8 \mathrm{~mL}$ with water and mixed with $6 \mathrm{~mL}$ of this reagent. Blank solution was prepared in the same manner, but replacing extracts with water. Antioxidant capacity was evaluated in correlation with the color change, by measuring absorbances at $450 \mathrm{~nm}$, using Trolox as a reference and a calibration curve $\left(R^{2}=0.992\right)$. Results were expressed as $\mu \mathrm{M}$ Trolox equivalents/g dry weight vegetal product and the assays were performed in triplicate [48].

\subsubsection{Cupric Ion Reducing Antioxidant Capacity (CUPRAC)}

The CUPRAC method is a spectrophotometric method based on the reduction of the copper ion (II) to the copper iron (I) in the neocupreine (2,9-dimethyl-1,10-phenantroline) complex. This reduction determines a color change from light green to red-orange. The change of color was correlated with the antioxidant capacity by measuring the absorbance at $450 \mathrm{~nm}$. The calibration curve was plotted using concentrations of the Trolox standard and results were expressed as $\mathrm{mM}$ Trolox equivalent/g dry weight vegetal product $[32,49,50]$.

\subsection{Cytotoxicity Assays}

Cytotoxicity study on tumoral cell lines was performed using the MTT assay (3-(4,5dimethylthiazol-2-yl)-2,5-diphenyl tetrazolium bromide; Sigma Aldrich) [51,52]. For both cell lines, the cells were plated $\left(1 \times 10^{5}\right.$ cells/well $)$ in 96-well plates for $24 \mathrm{~h}$ in normal propagation media ( $200 \mu \mathrm{L}$ cell suspention in each well). The extracts were added to the complete medium in five distinct volums $(5 \mu \mathrm{L}, 10 \mu \mathrm{L}, 15 \mu \mathrm{L}, 20 \mu \mathrm{L}, 25 \mu \mathrm{L})$, with the resulting concentrations $(\mathrm{C} 1, \mathrm{C} 2, \mathrm{C} 3, \mathrm{C} 4$ and $\mathrm{C} 5)$ calculated according to the TPC determined for each extracts and expressed as $\mu \mathrm{mol} \mathrm{GAE} / \mathrm{mL}$ as follows: flowers $(\mathrm{C} 1-11.69 \mu \mathrm{mol}$ $\mathrm{GAE} / \mathrm{mL}, \mathrm{C} 2-23.39 \mu \mathrm{mol} \mathrm{GAE} / \mathrm{mL}, \mathrm{C} 3-35.08 \mu \mathrm{mol} \mathrm{GAE} / \mathrm{mL}, \mathrm{C} 4-46.78 \mu \mathrm{mol} \mathrm{GAE} / \mathrm{mL}$, C5-58.475 $\mu \mathrm{mol} \mathrm{GAE} / \mathrm{mL}$ ), leaves (C1-11.34 $\mu \mathrm{mol} \mathrm{GAE} / \mathrm{mL}, \mathrm{C} 2-22.68 \mu \mathrm{mol} \mathrm{GAE} / \mathrm{mL}$, C3-34.02 $\mu \mathrm{mol} \mathrm{GAE} / \mathrm{mL}, \mathrm{C} 4-45.36 \mu \mathrm{mol} \mathrm{GAE} / \mathrm{mL}, \mathrm{C} 5-56.7 \mu \mathrm{mol} \mathrm{GAE} / \mathrm{mL}$ ), bark (C1-9.875 $\mu \mathrm{mol} \mathrm{GAE} / \mathrm{mL}, \mathrm{C} 2-19.75 \mu \mathrm{mol} \mathrm{GAE} / \mathrm{mL}, \mathrm{C} 3-29.625 \mu \mathrm{mol} \mathrm{GAE} / \mathrm{mL}, \mathrm{C} 4-$ $39.5 \mu \mathrm{mol} \mathrm{GAE} / \mathrm{mL}, \mathrm{C} 5-49.37 \mu \mathrm{mol} \mathrm{GAE} / \mathrm{mL})$ and fruit $(\mathrm{C} 1-6.66 \mu \mathrm{mol} \mathrm{GAE} / \mathrm{mL}, \mathrm{C} 2-$ 13.32 $\mu \mathrm{mol} \mathrm{GAE} / \mathrm{mL}, \mathrm{C} 3-19.98 \mu \mathrm{mol} \mathrm{GAE} / \mathrm{mL}, \mathrm{C} 4-26.64 \mu \mathrm{mol} \mathrm{GAE} / \mathrm{mL}, \mathrm{C} 5-33.2 \mu \mathrm{mol}$ $\mathrm{GAE} / \mathrm{mL}$ ). The negative control was represented by cells lines cultured in normal expansion medium (untreated cells), while $70 \% v / v$ ethanol and Cisplatin $(0.2 \mathrm{uM})$ were included as the internal control and the positive control, respectively.

The cells viability following $24 \mathrm{~h}$ incubation at $37^{\circ} \mathrm{C}$ in a humidified atmosphere with $5 \% \mathrm{CO}_{2}$ was evaluated using the MTT assay according to previously published protocol [51,52]. The formazan particles formed by adding $0.5 \mathrm{mg}$ MTT to each well were dissolved with dimethyl sulfoxide (DMSO) (Sigma Aldrich, St. Louis, MO, USA), and the absorbance was read at $450 \mathrm{~nm}$ using a microplate reader (Bio-Rad, Hercules, CA, USA). The cell viability percentages (\%) were calculated based on the absorbance ratio between cell cultures treated with extracts and the negative controls (untreated cells) multiplied by 100. For each extract, the cytotoxic activity expressed as $\mathrm{IC}_{50}$ values representing the extract concentration required to inhibit $50 \%$ of cell proliferation were calculated from the dose response curve obtained using non-linear regression. All experiments were performed in triplicates. 


\subsection{Statistical Analysis}

All statistical analyses were conducted using ANOVA GraphPad Prism software, version 6.0 (GraphPad, San Diego, CA, USA). The results were expressed as the mean \pm standard deviation (SD). One-way analysis of variance (ANOVA) was used, followed by Tukey's post hoc test, to determine statistical significance. The Pearson correlation analysis was performed to determine the correlation between extracts cytotoxic activity, total phenolic content and identified compounds, respectively. A $p$ value lower than 0.05 was considered statistically significant.

\section{Conclusions}

To the best of our knowledge, this is the first study aimed at evaluating and compare the chemical profile, antioxidative and antiproliferative properties of ethanolic extracts obtained from flowers, leaves, bark, and fruit of $S$. vulgaris. The performed methods highlighted that $S$. vulgaris extracts, in particular the ones obtained from flowers and leaves, are valuable sources of compounds with significant antioxidant and cytotoxic potential.

Author Contributions: Conceptualization, D.H., M.N., I.I., S.A., D.C.V., I.O., D.B.; methodology, M.N., N.-K.O., M.M., R.B., R.S., L.O., E.P., D.C.V., S.A.; software, M.N., I.I., N.-K.O., M.M., R.B., R.Ș., L.O., E.P., D.C.V., S.A.; validation, D.H., I.I., N.-K.O., M.M., R.B., R.Ș., L.O., E.P., D.C.V., S.A., D.B., I.O.; formal analysis, D.H., M.N., I.I., N.-K.O., M.M., R.B., R.S., L.O., E.P., D.C.V., S.A., D.B., I.O.; investigation, D.H., M.N., I.I., N.-K.O., M.M., R.B., R.S,., L.O., E.P., D.C.V., S.A., D.B., I.O.; resources, D.H., M.N., I.I., S.A., D.C.V., D.B., I.O.; data curation, D.H., M.N., I.I., N.-K.O., M.M., R.B., R.S., L.O., E.P., D.C.V., S.A., D.B., I.O; writing—original draft preparation, D.H., M.N., I.I., D.B., I.O.; writingreview and editing, D.H., I.I., M.N., N.-K.O., M.M., R.B., R.Ș., L.O., E.P., D.C.V., S.A., D.B., I.O.; visualization, D.H., M.N., I.I., N.-K.O., M.M., R.B., D.B., I.O.; supervision, D.H., M.N., I.I., N.-K.O., M.M., R.B., D.C.V., S.A., D.B., I.O.; project administration, D.H., M.N., N.-K.O., M.M., R.B., R.S., L.O., E.P., D.C.V., S.A., D.B., I.O.; funding acquisition, D.H., M.N., N.-K.O., M.M., R.B., R.Ș., L.O., E.P., D.C.V., S.A., D.B., I.O. All authors have read and agreed to the published version of the manuscript.

Funding: This research received no external funding.

Institutional Review Board Statement: Not applicable.

Informed Consent Statement: Not applicable.

Data Availability Statement: Data sharing not applicable.

Acknowledgments: We are grateful to retired research chemist Gheorghe Niculae for providing technical advice on Syringa vulgaris L. extracts.

Conflicts of Interest: The authors declare no conflict of interest.

Sample Availability: Samples of the compounds are not available from the authors.

\section{References}

1. Wozniak, M.; Michalak, B.; Wyszomierska, J.; Dudek, M.K.; Kiss, A.K. Effects of phytochemically characterized extracts from Syringa vulgaris and isolated secoiridoids on mediators of inflammation in a human neutrophil model. Front. Pharm. 2018, 9, 349. [CrossRef] [PubMed]

2. Simpson, M.G. Diversity and Classification of Flowering Plants: Eudicots. In Plant Systematics; Elsevier: Amsterdam, The Netherlands, 2010; Volume 315, pp. 275-448.

3. Lendvay, B.; Kadereit, J.W.; Westberg, E.; Cornejo, C.; Pedryc, A.; Höhn, M. Phylogeography of Syringa josikaea (Oleaceae): Early Pleistocene divergence from East Asian relatives and survival in small populations in the Carpathians. Biol. J. Linn. Soc. 2016, 119, 689-703. [CrossRef]

4. Su, G.; Cao, Y.; Li, C.; Yu, X.; Gao, X.; Tu, P.; Chai, X. Phytochemical and pharmacological progress on the genus Syringa. Chem. Cent. J. 2015, 9, 2. [CrossRef] [PubMed]

5. Zhu, W.; Wang, Z.; Sun, Y.; Yang, B.; Wang, Q.; Kuang, H. Traditional uses, phytochemistry and pharmacology of genus Syringa: A comprehensive review. J. Ethnopharmacol. 2021, 26, 113465. [CrossRef] [PubMed]

6. Hanlidou, E.; Karousou, R.; Kleftoyanni, V.; Kokkini, S. The herbal market of Thessaloniki (N Greece) and its relation to the ethnobotanical tradition. J. Ethnopharmacol. 2004, 91, 281-299. [CrossRef] [PubMed]

7. Jarić, S.; MačUkanović-Jocić, M.; Djurdjević, L.; Mitrović, M.; Kostić, O.; Karadžić, B.; Pavlović, P. An ethnobotanical survey of traditionally used plants on Suva planina mountain (south-eastern Serbia). J. Ethnopharmacol. 2015, 175, 93-108. [CrossRef] 
8. Leporatti, M.L.; Ivancheva, S. Preliminary comparative analysis of medicinal plants used in the traditional medicine of Bulgaria and Italy. J. Ethnopharmacol. 2003, 87, 123-142. [CrossRef]

9. Papp, N.; Birkás-Frendl, K.; Bencsik, T.; Stranczinger, S.; Czégényi, D. Survey of traditional beliefs in the Hungarian Csángó and Székely ethnomedicine in Transylvania, Romania. Braz. J. Pharm. 2014, 24, 141-152. [CrossRef]

10. Tóth, G.; Barabás, C.; Tóth, A.; Kéry, Á.; Béni, S.; Boldizsár, I.; Varga, E.; Noszál, B. Characterization of antioxidant phenolics in Syringa vulgaris L. flowers and fruits by HPLC-DAD-ESI-MS. Biomed. Chromatogr. 2016, 30, 923-932. [CrossRef] [PubMed]

11. Varga, E.; Barabás, C.; Tóth, A.; Boldizsár, I.; Noszál, B.; Tóth, G. Phenolic composition, antioxidant and antinociceptive activities of Syringa vulgaris L. bark and leaf extracts. Nat. Prod. Res. 2019, 33, 1664-1669. [CrossRef]

12. Ao, W.L.J.; Wang, Q.H.; Si-Qin; Mu-Dan; Sa-Ren-Tu-Ya; Dai, N.Y.T.; Du-Ri-Si-Ha-La-Tu. The structural elucidation and antimicrobial activities of two new sesquiterpenes from Syringa pinnatifolia Hemsl. Chin. J. Nat. Med. 2012, 10, 477-480. [CrossRef]

13. Dudek, M.K.; Michalak, B.; Woźniak, M.; Czerwińska, M.E.; Filipek, A.; Granica, S.; Kiss, A.K. Hydroxycinnamoyl derivatives and secoiridoid glycoside derivatives from Syringa vulgaris flowers and their effects on the pro-inflammatory responses of human neutrophils. Fitoterapia 2017, 121, 194-205. [CrossRef] [PubMed]

14. Filipek, A.; Wyszomierska, J.; Michalak, B.; Kiss, A.K. Syringa vulgaris bark as a source of compounds affecting the release of inflammatory mediators from human neutrophils and monocytes/macrophages. Phytochem. Lett. 2019, 30, 309-313. [CrossRef]

15. Oku, H.; Maeda, M.; Kitagawa, F.; Ishiguro, K. Effect of polyphenols from Syringa vulgaris on blood stasis syndrome. J. Clin. Biochem. Nutr. 2020, 67, 84-88. [CrossRef]

16. Su, G.; Zhang, R.; Yang, X.; Bai, R.; Yin, X.; Gao, X.; Li, L.; Tu, P.; Chai, X. Lignans from the stem bark of Syringa pinnatifolia. Fitoterapia 2016, 114, 63-68. [CrossRef] [PubMed]

17. Krishnan, S.S.C.; Subramanian, I.P.; Subramanian, S.P. Isolation, characterization of syringin, phenylpropanoid glycoside from Musa paradisiaca tepal extract and evaluation of its antidiabetic effect in streptozotocin-induced diabetic rats. Biomed. Prev. Nutr. 2014, 4, 105-111. [CrossRef]

18. Kikuchi, M.; Yaoita, Y.; Mano, N.; Kikuchi, M. Glycosides from the Leaves of Syringa vulgaris and Their Growth Inhibitory Activity against Human Cancer Cell Lines. Jpn. Soc. Pharm. 2010, 64, 104-105.

19. Qi, L.M.; Zhang, J.; Zhao, Y.L.; Zuo, Z.T.; Jin, H.; Wang, Y.Z. Quantitative and qualitative characterization of Gentiana rigescens Franch (Gentianaceae) on different parts and cultivations years by HPLC and FTIR spectroscopy. J. Anal. Methods Chem. 2017, 2017. [CrossRef]

20. Mosoarca, G.; Vancea, C.; Popa, S.; Gheju, M.; Boran, S. Syringa vulgaris leaves powder a novel low-cost adsorbent for methylene blue removal: Isotherms, kinetics, thermodynamic and optimization by Taguchi method. Sci. Rep. 2020, 10, 17676. [CrossRef]

21. Kenđel, A.; Zimmermann, B. Chemical Analysis of Pollen by FT-Raman and FTIR Spectroscopies. Front. Plant Sci. 2020, 11, 352. [CrossRef]

22. Schulz, H.; Pfeffer, S.; Quilitzsch, R.; Steuer, B.; Reif, K. Rapid and non-destructive determination of the echinacoside content in Echinacea roots by ATR-IR and NIR spectroscopy. Planta Med. 2002, 68, 926-929. [CrossRef] [PubMed]

23. Agatonovic-Kustrin, S.; Ristivojevic, P.; Gegechkori, V.; Litvinova, T.M.; Morton, D.W. Essential oil quality and purity evaluation via ft-ir spectroscopy and pattern recognition techniques. Appl. Sci. 2020, 10, 7294. [CrossRef]

24. Yang, Y.; Zhao, Y.; Zuo, Z.; Zhang, J.; Shi, Y.; Wang, Y. Investigation of a medical plant for hepatic diseases with secoiridoids using HPLC and FT-IR spectroscopy for a case of gentiana rigescens. Molecules 2020, 25, 1219. [CrossRef] [PubMed]

25. Qi, L.M.; Zhang, J.; Zuo, Z.T.; Zhao, Y.L.; Wang, Y.Z.; Hang, J. Determination of Iridoids in Gentiana rigescens by Infrared Spectroscopy and Multivariate Analysis. Anal. Lett. 2017, 50, 389-401. [CrossRef]

26. Min, X.; Dong, W.; Jun, Z.Y.; Chong-Ren, Y. A New Secoiridoidal Secoiridoidal Glucoside from Gentiana rigescens (Gentianaceae). Acta Bot. Yunnanica 2006, 28, 669-672.

27. Selvaraj, K.; Chowdhury, R.; Bhattacharjee, C. Isolation and structural elucidation of flavonoids from aquatic fern Azolla microphylla and evaluation of free radical scavenging activity. Int. J. Pharm. Pharm. Sci. 2013, 5 (Suppl. 3), 743-749.

28. Bakkialakshmi, S.; Roy, J. Infrared Spectrum Analysis of Some Flavonoids with Hemoglobin. Int. J. Appl. Adv. Sci. Res. 2017, 2, 107-110.

29. Crişan, I.; Vidican, R.; Olar, L.; Stoian, V.; Morea, A.; Ştefan, R. Screening for Changes on Iris germanica L. Rhizomes following inoculation with arbuscular mycorrhiza using Fourier transform infrared spectroscopy. Agronomy 2019, 9, 815. [CrossRef]

30. Kowczyk-Sadowy, M.; Wisłocka, R.; Lewandowska, H.; Piekut, J.; Lewandowski, W. Spectroscopic (FT-IR, FT-Raman, 1HAnd13C-NMR), theoretical and microbiological study of trans o-coumaric acid and alkali metal o-coumarates. Molecules 2015, 20, 3146-3369. [CrossRef]

31. Ielciu, I.; Sevastre, B.; Olah, N.-K.; Turdean, A.; Chişe, E.; Marica, R.; Oniga, I.; Uifălean, A.; Sevastre-Berghian, A.C.; Niculae, M.; et al. Evaluation of Hepatoprotective Activity and Oxidative Stress Reduction of Rosmarinus officinalis L. Shoots Tincture in Rats with Experimentally Induced Hepatotoxicity. Molecules 2021, 26, 1737. [CrossRef] [PubMed]

32. Ielciu, I.; Hanganu, D.; Păltinean, R.; Vlase, L.; Frédérich, M.; Gheldiu, A.-M.; Benedec, D.; Crişan, G. Antioxidant capacity and polyphenolic content of the Echinocystis lobata (Michx.) Torr. et A.Gray flowers. Pak. J. Pharm. Sci. 2018, 31 (Suppl. 2 ), $677-683$.

33. Ielciu, I.; Frederich, M.; Hanganu, D.; Angenot, L.; Olah, N.-K.; Ledoux, A.; Crişan, G.; Păltinean, R. Flavonoid Analysis and Antioxidant Activities of the Bryonia alba L. Aerial Parts. Antioxidants 2019, 8, 108. [CrossRef] 
34. Castejón, M.L.; Montoya, T.; Alarcón-de-la-Lastra, C.; Sánchez-Hidalgo, M. Potential protective role exerted by secoiridoids from Olea europaea L. in cancer, cardiovascular, neurodegenerative, aging-related, and immunoinflammatory diseases. Antioxidants 2020, 9, 149. [CrossRef]

35. Taleghani, A.; Tayarani-Najaran, Z. Potent Cytotoxic Natural Flavonoids: The Limits of Perspective. Curr. Pharm. Des. 2019, 24, 5555-5579. [CrossRef] [PubMed]

36. Neelam, A.K.; Sharma, K.K. Phenylpropanoids and its derivatives: Biological activities and its role in food, pharmaceutical and cosmetic industries. Crit. Rev. Food Sci. Nutr. 2020, 60, 2655-2675. [CrossRef]

37. Karihtala, P.; Soini, Y. Reactive oxygen species and antioxidant mechanisms in human tissues and their relation to malignancies. Apmis 2007, 115, 81-103. [CrossRef]

38. Aung, T.N.; Qu, Z.; Kortschak, R.D.; Adelson, D.L. Understanding the effectiveness of natural compound mixtures in cancer through their molecular mode of action. Int. J. Mol. Sci. 2017, 18, 656. [CrossRef]

39. Huang, C.Y.; Ju, D.T.; Chang, C.F.; Muralidhar, R.P.; Velmurugan, B.K. A review on the effects of current chemotherapy drugs and natural agents in treating non-small cell lung cancer. Biomededicine 2017, 7, 12-23. [CrossRef]

40. Kikuchi, M.; Yaoita, Y.; Mano, N.; Kikuchi, M. Structure and Cytotoxic Activity of Enzymatic Hydrolysis Products of Secoiridoid Glucosides, Isoligustroside and Isooleuropein. Chem. Biodivers. 2011, 8, 651-657. [CrossRef]

41. Ielciu, I.; Mouithys-Mickalad, A.; Franck, T.; Angenot, L.; Ledoux, A.; Păltinean, R.; Cieckiewicz, E.; Etienne, D.; Tits, M.; Crişan, G.; et al. Flavonoid composition, cellular antioxidant activity and (myelo)peroxidase inhibition of a Bryonia alba L. (Cucurbitaceae) leaves extract. J. Pharm. Pharm. 2019, 71, 230-239. [CrossRef]

42. Bădălica-Petrescu, M.; Drăgan, S.; Ranga, F.; Fetea, F.; Socaciu, C. Comparative HPLC-DAD-ESI(+)MS fingerprint and quantification of phenolic and flavonoid composition of aqueous leaf extracts of Cornus mas and Crataegus monogyna, in relation to their cardiotonic potential. Not. Bot. Horti Agrobot. 2014, 42, 9-18. [CrossRef]

43. Hanganu, D.; Benedec, D.; Olah, N.-K.; Ranga, F.; Mirel, S.; Tiperciuc, B.; Oniga, I. Research on enzyme inhibition potential and phenolic compounds from Origanum vulgare ssp. vulgare. Farmacia 2020, 68, 1075-1080. [CrossRef]

44. Sevastre-Berghian, A.C.; Ielciu, I.; Mitre, A.O.; Filip, G.A.; Oniga, I.; Vlase, L.; Benedec, D.; Gheldiu, A.-M.; Toma, V.A.; Miharţ, B.; et al. Targeting Oxidative Stress Reduction and Inhibition of HDAC1, MECP2, and NF-kB Pathways in Rats with Experimentally Induced Hyperglycemia by Administration of Thymus marshallianus Willd. Extracts. Front. Pharm. 2020, 11, 581470. [CrossRef]

45. Stan, M.S.; Voicu, S.N.; Căruntu, S.; Nica, I.C.; Olah, N.-K.; Burtescu, R.; Balta, C.; Rosu, M.; Herman, H.; Hermenean, A.; et al. Antioxidant and anti-inflammatory properties of a Thuja occidentalis mother tincture for the treatment of ulcerative colitis. Antioxidants 2019, 8, 416. [CrossRef] [PubMed]

46. Moț, A.C.; Damian, G.; Sârbu, C.; Silaghi-Dumitrescu, R. Redox reactivity in propolis: Direct detection of free radicals in basic medium and interaction with hemoglobin. Redox Rep. 2009, 14, 267-274. [CrossRef]

47. Benzie, I.; Strain, J. The ferric reducing ability of plasma (FRAP) as a measure of "antioxidant power": The FRAP assay. Anal. Biochem. 1996, 239, 70-76. [CrossRef]

48. Oniga, I.; Puşcaş, C.; Silaghi-Dumitrescu, R.; Olah, N.-K.; Sevastre, B.; Marica, R.; Marcus, I.; Sevastre-Berghian, A.C.; Benedec, D.; Pop, C.E.; et al. Origanum vulgare ssp. vulgare: Chemical composition and biological studies. Molecules 2018, $23,2077$.

49. Özyürek, M.; Güngör, N.; Baki, S.; Güçlü, K.; Apak, R. Development of a silver nanoparticle-based method for the antioxidant capacity measurement of polyphenols. Anal. Chem. 2012, 84, 8052-8059. [CrossRef]

50. Olah, N.-K.; Osser, G.; Câmpean, R.F.; Furtuna, F.R.; Benedec, D.; Filip, L.; Raita, O.; Hanganu, D. The study of polyphenolic compounds profile of some Rosmarinus officinalis L. extracts. Pak. J. Pharm. Sci. 2016, 29 (Suppl. 6), $2355-2361$.

51. Iacoviţă, C.; Florea, A.; Scoruş, L.; Pall, E.; Dudric, R.; Moldovan, A.I.; Ştiufiuc, R.; Tetean, R.; Lucaciu, C.M. Hyperthermia, cytotoxicity, and cellular uptake properties of manganese and zinc ferrite magnetic nanoparticles synthesized by a polyolmediated process. Nanomaterials 2019, 9, 1489. [CrossRef]

52. Marian, E.; Duteanu, N.; Vicas, L.; Rusu, G.; Jurca, T.; Muresan, M.; Micle, O.; Hangan, A.C.; Stan, R.L.; Ionescu, C.; et al. Synthesis, characterization of inclusion compounds of amygdalin with $\beta$-cyclodextrin and sod-like activity and cytotoxicity on hela tumor cells. Arab. J. Chem. 2020, 13, 6828-6837. [CrossRef] 